\title{
Historie alternatywne - pomiędzy pisarstwem historycznym a fantastycznym, czyli czasem tertium est datur...
}

To, co inne, jest fantazmatem historiografii'.

Niech dziejopis zastanawia się nad nieurzeczywistnionymi działaniami, badacz architektury nad architektura, która nie powstata, filolog niech rozmyśla nad nienapisanymi tekstami, filozof - nad ideami, których nie sformutowano ${ }^{2}$.

Celem niniejszego artykułu jest przewrotne wyprowadzenie konsekwencji z dość często podnoszonych we współczesnej humanistyce kwestii zmienionych regul wytwarzania i dystrybucji wiedzy, czyli jej wyjścia poza krąg akademii, a z drugiej strony rozmywania się granic pomiędzy konkretnymi dziedzinami nauk humanistycznych. Zamierzam bowiem zaproponować zdefiniowanie historii alternatywnych, gatunku literackiego tradycyjnie lokowanego w obrębie literatury fantastycznej ${ }^{3}$, jako uczestniczącego w posze-

De Certeau 2001: 110.

Demandt 1999: 20. Pisownia słowa „nieurzeczywistnione” zgodna z oryginałem: N.L.

Owszechnie uznawana teza jest moim zdaniem pewnym uproszczeniem. Lokowanie chociażby późnych powieści Teodora Parnickiego (Sam wyjdę bezbronny, Muza dalekich podróży, Inne życie Kleopatry i in.) w nurcie science fiction jest wątpliwe, a przynajmniej wymagałoby znacznych modyfikacji samego terminu. Również takie powieści, jak Pociąg do podróży Andrzeja Barta, Krfotok Edwarda Redlińskiego, Ziemia pod jej stopami Salmana Rushdiego, Spisek przeciwko Ameryce Philippa Rotha, Turbot Güntera Grassa, Historia oblężenia Lizbony Jose Saramago, Baudolino Umberta Eco, Przypadek Adolfa H. Ericha E. Schmitta i in., nie powinny być określane mianem fantastyki. Rozważania genealogiczno-taksonomiczne niestety znacznie jednak wykraczają poza zakres 
rzonej formule pisarstwa historycznego. Zgodnie z terminologią zaproponowaną ostatnimi czasy przez Haydena Whitea [2009; 2014] historie alternatywne można uznać za gatunek pisarstwa historycznego czy prozy historycznej. Badacz ten przyznat: „[... po wieloletnich studiach jestem przekonany, że pisarstwo historyczne ujęte w formę narracji [...] jest rodzajem literatury" [White 2009: 17] i podkreślił równocześnie, że nie ma niepodważalnej, esencjalnej różnicy pomiędzy prozą historyczną a literacką.

Różnica pomiędzy historią a literaturą może jawić się jako opozycja pomiędzy światem rzeczywistym (przeszłym i teraźniejszym) a fantazją, marzeniami i innymi fantazmatycznymi czynnikami (iluzje, złudzenia, fobie i tak dalej) jedynie wówczas, gdy fikcję utożsamimy z pisarstwem na temat fantastycznych istot, a literaturę z fikcją. [White 2009: 13]

Co szczególnie interesujące dla niniejszego szkicu, White otwarcie uznał Spisek przeciw Ameryce Philipa Rotha [2007], powieść realizującą reguły gatunkowe historii alternatywnych, za przykład prozy historycznej:

[... ] nie jest klasyfikowane jako „fikcja”, chociaż [ ... ] napisane jest w jednoznacznie „literackim” stylu. [...] Ostatecznym odniesieniem jest „historia” nawet jeśli forma jej reprezentacji jest wyobrażeniowa. [...] Obie powieści [White wspomina też o Austerlitz Winfreda Georga Sebalda - N.L] są doskonałymi przykładami tego, co nazywam „prozą historyczną”. [White 2009: 17]

W optyce tego badacza powieść Rotha przynależy do dziedziny tzw. przeszłości praktycznej [White 2014: 48, 62]. Ta zaś (autorem

tego artykułu. Wydaje się, że historie alternatywne mogą być pojmowane jako para-i ponadgenologiczny czynnik, funkcjonujący na przykład w obrębie epickiej historiografii (Natalia Lemann) jako literatury „uświadomionej” historycznie i historiograficznie, czy też zgodnie z propozycją Edwarda Balcerzana [200o] jako intencja alternatywno-historyczna, aktualizowana po-między rozmaitymi gatunkami czy dyskursami. 
pojęcia przeszłość praktyczna jest Michael Oakshott) odnosi się do przekonań na temat przeszłości, których każdy człowiek dowodzi w życiu codziennym, gdyż pomagają one rozwiązywać problemy, począwszy od spraw osobistych, a na politycznych kończąc. Zdaniem White'a jest „to przeszłość pamięci, marzenia i pragnień” [White 2014: 52], skoro „Praktyczną przeszłość wspomnień, snów, fantazji, doświadczenia czy wyobraźni przywołujemy, skonfrontowani z pytaniem: «co powinienem zrobić?»" [White 2014: 53]. Przeszłość praktyczna jest zatem przeciwieństwem przeszłości historycznej w sensie naukowym, ta bowiem zdaniem holenderskiego badacza nie ma przełożenia na ludzką możliwość dokonywania świadomych wyborów, gdyż jest skrzętnie izolowana od życia. Powieści z gatunku historii alternatywnych, będące składową przeszłości praktycznej, mają równocześnie swój udział w postmodernistycznej schedzie, skoro, jak podkreśla White [2014: 61]: „tylko niewielu osobom przyszło do głowy zaznaczyć, że gatunkiem i trybem pisania dominującym w pisarstwie postmodernistycznym jest powieść (neo)historyczna" [zob. Elias 2001; por. White 2009: 77]. W postmodernistycznym podejściu do przeszłości silnie zaznaczony jest wymiar fantazmatyczny („powrót wypartego”, brzemię, duch), zaś sama przeszłość staje się „miejscem fantazji, przyjemności, gry form czy nawet utopijnych możliwości” [White 2014: 37]. Owo freudowskie podejście do przeszłości, ujęcie jej w kategoriach fantazmatu - zarówno oswajania, kojenia traum, jak i ich ponownej intronizacji - ma istotne znaczenie dla poetyki i terapeutycznej funkcji historii alternatywnych [Lemann 2011, 2013, 2014a]. Przywoływany w motcie do tego szkicu Michel de Certeau stwierdził, że „fikcja jest wypartym innym historii” [cyt. za: White 2014: 50] oraz że „to, co inne, jest fantazmatem historii” [de Certeau 2001: 110]. Maria Janion [2001: 163] w swym projekcie krytyki fantazmatycznej przypomina, że fantazmat zakorzeniony jest w nieuświadomionym i jest derywatem marzenia, derywatem mającym nostalgiczny charakter: „Lepsze jest «tam», gorsze jest «tutaj»”. Sam Freud nie mógł się zdecydować - jak przypomina Janion [2011: 163] - czy „fantazmat ujmuje wydarzenia, które rzeczywiście się dokonały, czy też jest zupełnie fikcyjną konstrukcją wyobrażeniową?"; dlatego też ostatecznie przyjął, że w obrębie 
fantazmatów granice pomiędzy rzeczywistością a wyobraźnią są zatarte. Fantazmatyczność - aporetyczne zawieszenie pomiędzy jawą a snem, wyobraźnią, marzeniem a rzeczywistością - jest zatem nieredukowalnym elementem historiografii, zaś postulowana przez de Certeau inność może być rozumiana szeroko - jako inny od klasycznego sposób spisywania narracji historycznej czy pewne „wyparte”, niepożądane przez klasycznych historyków procedury dociekań naukowych, jakimi są operacje kontrfaktyczne, prostą drogą wiodące do historii alternatywnych, i to zarówno w wymiarze powieściowym, jak i eseistyczno-naukowym. Jak wiadomo, jedyną formą uwolnienia się od natręctwa fantazmatów jest ich przyswojenie, dopuszczenie do głosu. Dlatego też procedury kontrfaktyczne i historie alternatywne, stanowiące owo wyparte „inne” historiografii (i do pewnego stopnia literaturoznawstwa), domagają się swego miejsca na arenie akademickiej.

Fenomen niezwykłej czytelniczej popularności literackich historii alternatywnych z jednej strony, z drugiej zaś, eufemistycznie mówiąc, ambiwalentny stosunek akademików (zarówno historyków, jak i literaturoznawców) do tego typu literatury, wykracza moim zdaniem, poza zainteresowanie socjologii literatury czy teorii recepcji. Fakt, iż wyżej wspomniany gatunek literacki oraz jego historyczny odpowiednik, historie kontrfaktyczne (o których szerzej napiszę poniżej), są w znacznej mierze odpowiedzialne za kształtowanie świadomości historycznej [Maternicki 1984, 1990, 1998; Rosenfeld 2002, 2005], nie musi być traktowany jako zagrożenie. Wprost przeciwnie, może zostać uznany za sposób wyjścia z impasu i impuls do odnowienia, re-formacji literaturoznawstwa i historii, czy nawet do ponownego i bardziej świadomego odbudowania przebiegających „wszędzie współcześnie granic” między poszczególnymi naukami [Domańska 2011]. Może więc liminalność nie musi oznaczać niepewności i naukowej labilności ontologicznej, a w zamian może stać się radosnym manifestem ery konwergencji [Jenkins 2007], świadomej możności przekraczania wyczuwalnego jednak limesu i transgresyjnego bycia po-między dyscyplinami, a w efekcie re-figuracji pola humanistycznej wiedzy i dyscyplin? Humanistyka winna być przecież postrzegana holistycznie, bez względu na to, jaki wycinek ludzkiej działalności 
i refleksji bada, bo przecież, zgodnie z dewizą Terencjusza: „Człowiek jestem; nic co ludzkie nie jest mi obce”.

Współczesna humanistyka trawiona jest najwyraźniej dwoma bardziej chyba aporetycznymi niż przeciwstawnymi tendencjami. $\mathrm{Z}$ jednej strony jest to postulowana $\mathrm{z}$ ław akademii profesjonalizacja wiedzy, roszcząca sobie prawo do wyłącznego dostępu i wytwarzania wiedzy [por. Nycz 2006: 22-27], oraz podtrzymywanie jej autonomicznego wobec innych dziedzin humanistycznych statusu. Z drugiej jednak strony, jako odpowiedź na kryzys poznania, daje się zauważyć tendencja wynikająca ze świadomości schyłkowości owego uprzywilejowania poznawczego i prób wyjścia z impasu, między innymi poprzez holistyczny projekt humanistyki bardziej trans- niż interdyscyplinarnej. Anna Zeidler-Janiszewska [2006: 10] przypomina, iż

Uświadamiamy sobie coraz wyraźniej, że granice dzielące dyscypliny nie mają charakteru teoretycznego, lecz historyczny i - jako takie - mogą być nie tylko przekraczane, ale i przesuwane, modyfikowane i zmieniane w progi, które zapraszają do różnokierunkowych przejść. [...] transdyscyplinarność staje się koniecznością drugiej fazy nowoczesności [...] to właśnie jej wysoki poziom i rozwinięte specjalizacje stanowią podstawowy warunek transdyscyplinarności.

Te dwie tendencje doskonale obrazują współczesne relacje pomiędzy historią a literaturoznawstwem. Mimo iż nauki te przez długie lata/wieki wiodły metodologiczne (nie do końca) równoległe żywoty [Lemann 2007, 2008, 2012a; White 2009: 27-28, 80, 2014: 43-66], wciąż stają przed powracającą kwestią negocjacji wzajemnych odrębności i granic, jako że dopiero dziś odzyskiwana jest dawna świadomość tego, iż historia i literatura wywodzą się ze wspólnego pnia i do końca XVIII w. nie były od siebie rozdzielane. Znamienną ilustracją może być fakt, że stanowisko oficjalnego historiografa Ludwika XIV piastowali... dramaturg Jean-Baptise Racine oraz Nicolas Boileau-Despréaux, autor Sztuki poetyckiej.

Kwestia obecności żywiołu literackiego w obrębie narracji historycznej, a także problem utraty monopolu na wiedzę 
historyczną budzą wśród historyków głębokie kontrowersje. Nie wszystkim bowiem tak samo łatwo jest dostosować się do zmieniających się dynamicznie reguł wytwarzania i kolportowania wiedzy, co po raz kolejny dowodzi, że nie wszyscy są równie chętni do negocjowania swego słownika ze światem, wiedząc, iż żaden z nich nie jest ostateczny. Przykładowo wybitny i poczytny historyk Marcin Kula [2011: 311], badając reportaż historyczny jako rodzaj współczesnej historiografii, twierdzi, że „historiografia winna być albo naukowa (historiografia faktograficzna) albo ciekawa do czytania. Tertium non datur". Ten wybitny historyk unieważnia więc znaczenie literackiej świetności dawnych dokonań historiografii, a warto chociażby pamiętać, że w roku 1902 literacką Nagrodę Nobla odebrał Theodor Mommsen za Historię Rzymu. Andrzej Radomski [2012: 82], zwolennik otwierania granic akademii, odważnie podnosi kluczową kwestię: „[... ] dlaczego tylko akademicka historiografia ma mieć monopol na tworzenie wiarygodnej wiedzy historycznej czy w ogóle wiedzy historycznej?", zaś Krzysztof Pomian [2006: 231] powiada: „Dzisiaj, gdy nieustannie burzony i nieustannie odbudowywany mur oddziela historię od fikcji literackiej, historycy uniwersyteccy nie mają już powodów natury epistemologicznej, by odmawiać miana historii znacznej części prac, których autorzy nie wywodzą się z ich cechu”.

Są jednak i tacy badacze, którzy wykorzystując rozluźnienie metodologicznych granic, postanowili dokonać swego rodzaju „inkorporacji” gatunków tradycyjnie lokowanych w obrębie piśmiennictwa literaturoznawczego. Znakomitym przykładem jest Mark Phillips, który proponuje, by na przykład biografię czy historię literatury wprowadzić w obręb gatunków pisarstwa historycznego. Badacz ten postuluje „podejście [...] łączące pełen zakres literatur, które mają za zadanie przedstawienie historii - przenoszącego bardziej konwencjonalne formy historii w bliższą relację z rozległą rodziną gatunków historycznego opisu" [Phillips 2011: 129; wyróż. - N.L.]. W ten sposób wyraża on swój sprzeciw wobec uznania historii za stabilny, godny miana literatury monolit, w zamian zaś proponuje widzieć ją jako „zlepek nachodzących na siebie i konkurujących ze sobą gatunków, zarówno «niskich», jak i «wysokich»" [Phillips 2011: 130; wyróż. - N.L.], dających dużo 
pełniejszy obraz myśli historycznej, która „potrafi lepiej dostosować się do wielu metod, ideologii i retoryk, składających się na praktykę każdej epoki w historiografii” [Phillips 2011: 130]. Pomian [2006: 231] ująi to następująco: „Nie istnieje zatem jeden jedyny sposób pisania o historii. Jest ich wiele i są bardzo różne".

Phillips, sięgając po gatunki literaturoznawcze, zaprasza niejako do gestu odwrotnego, do wprowadzenia w obręb szeroko rozumianej „prozy historycznej” gatunków literackich, i to nie powieści historycznej, metapowieści historiograficznej [Hutcheon 1997], powieści palimpsestowej [Brooke-Rose 1996] czy epickiej historiografii [Lemann 2007, 2008], ale tzw. gatunków „niskich”, rodem z literatury popularnej, fantastycznej (o „niskie” gatunki dopominał się przecież Phillips), takich jak historie alternatywne. Należy jednak pamiętać, że historie alternatywne opuściły już niszę literatury popularnej i coraz odważniej zdobywają sobie miejsce pośród literatury tzw. mainstreamowej, a nawet wysokoartystycznej. Historię alternatywną napisali na przykład Peter Aycroyd (Milton in America, 1996) czy Philip Roth (Spisek przeciwko Ameryce, 2004). Ten ostatni jest jednym z najznakomitszych współczesnych pisarzy amerykańskich, a fakt, że napisał historię alternatywną, można uznać za przykład „afirmacji gatunku i wprowadzenia go do amerykańskiego mainstreamu" [Rosenfeld 2005: 152]. Z kolei Thomas Pynchon w metapowieści historiograficznej Against the Day (2006) sięgnął po konwencję steampunku, który jest podtypem historii alternatywnych [por. Lemann 2014b]. W literaturze polskiej dowodem swoistej nobilitacji historii alternatywnych mogą być następujące powieści: Pociag do podróży Andrzeja Barta, Krfotok Edwarda Redlińskiego czy powieści Teodora Parnickiego: Sam wyjdę bezbronny, Drugie życie Kleopatry, Muza dalekich podróży. Również Lód Jacka Dukaja czy Widma zdecydowanie wykraczają poza niszę literatury popularnej. Gavriel Rosenfeld [2002: 91] słusznie twierdzi, że historie alternatywne to prawdziwy fenomen współczesnej kultury Zachodu, obecny nie tylko w literaturze, lecz także chociażby w kinie (np. filmy typu Bękarty wojny Quentina Tarantino) czy w filmoznawstwie [zob. Lubelski 2012]).

$\mathrm{Na}$ wpisanie historii alternatywnych w projekt prozy historycznej Haydena White'a pozwalają następujące, doskonale znane 
ujęcia genologiczne, między innymi koncepcja sylwiczności literatury [Nycz 1984], gatunków rozmytych/zmąconych [Geertz 1996], projekt genologii multimedialnej [Balcerzan 1999], „niedostrzeżony problem podstawowy genologii” [Skwarczyńska 1970] czy pojęcia politypiczne [Sawicki 1976]. Zmienione reguły genologii pozwalają na rozpatrywanie międzygatunkowego, hybrydycznego oblicza współczesnej literatury, wymuszającego na badaczu transdyscyplinarne migrowanie po-między i negocjowanie sensów wyprowadzanych z analizowanych tekstów. Historie alternatywne mogą być więc równocześnie gatunkiem literatury popularnej, jak i uczestniczyć w opisywanym przez Phillipsa elastycznym konstruowaniu obrazu myśli historycznej, wspóltworzyć świadomość społeczną historii, przybliżać czytelnikowi ważkie kwestie historiograficzne, zaznajamiać z procedurami krytyki źródeł, prezentować efekty heurezy, wysuwając epistemologiczne sądy historyczne. Jeśli wspominani notabene przez Phillipsa mikrohistorycy mogli sięgać po stricte literacki tryb pisania, by prezentować efekty swych naukowych badań, to nic nie stoi na przeszkodzie, by w dobie konwergencji, swobodnego przepływu treści pomiędzy różnymi platformami medialnymi, procesualności wiedzy i jej demokratyzacji tudzież rozmycia to pisarze wydatnie przyczyniali się do edukacji historycznej czy wzrostu zainteresowania historią bądź rozbudzania i kształtowania świadomości historycznej.

Wielokrotnie tu już cytowany White [2009: 11] twierdził, że wszelkie wnioskowanie o przeszłości „pozostać musi jedynie możliwością, a zatem fikcją", co w dość przewrotny sposób odwołuje się do dokonanej przez Arystotelesa [1983: 330] dystynkcji pomiędzy poezją a historią: „[... ] historyk mówi o wydarzeniach, które miały miejsce w rzeczywistości, drugi zaś o takich, które mogą się wydarzyć”. Dystynkcja Stagiryty pozwala więc uznać, że wszelkie, $\mathrm{w}$ tym historyczne, scenariusze alternatywne są domeną literatury. Catherine Gallagher ${ }^{4}$ [2012: 143] z cytowanego fragmentu Poetyki

Zastanawiająca jest skala popularności tekstu Gallagher w Polsce. Tymczasem poza artykułem opublikowanym na łamach „Tekstów Drugich” autorka ta nie zajmuje się historiami alternatywnymi, gros spośród jej tez ma charakter doraźnych rozpoznań, zaś baza bibliograficzna, na której buduje swój tekst, jest więcej niż skromna. 
wyprowadza wniosek, że historia to dziedzina bardziej filozoficzna, gdyż wiąże się z nieprzewidywalnymi okolicznościami, a zatem historia alternatywna „rojąca się od przypadkowych wydarzeń stanowi skrajną wizję nieprzewidywalności dziejów”. Należy zgodzić się z tym, że historia alternatywna, jako gatunek prozy fikcjonalnej, spekulatywnej, twórczo rozwijający spekulacje probabilistyczne w historii, odpowiadając na pytanie: „co by było, gdyby”, rozgrywający się w świecie, w którym wydarzenia historyczne miały przebieg odmienny niż ten znany ze świata rzeczywistego [Fergusson, ed. 1997; Hellekson 2001; Rosenfeld 2002, 2005; Danneberg 2008; Lemann 2012b], ewokuje antydeterministyczną wersję dziejów [por. Łotman 1997: 34; Black 2008: 5]. Gallagher oskarża jednak cały gatunek historii alternatywnych o nadmierną, nieumotywowaną spekulatywność. Niewypowiedzianą tezą badaczki wydaje się konstatacja, że literackie historie alternatywne stanową „gorszą” wersję operacji kontrfaktycznych, którymi posługują się historycy. Co więcej, Gallagher zdaje się sugerować, że pomiędzy alternatywami rozważanymi przez historyków i pisarzy wciąż istnieje jakaś niezbywalna jakościowa różnica. Czyżby kontrfaktualizm przerastał pod tym względem narrację historyczną? Już przecież Roland Barthes [1984: 237] podważał istnienie wyraźnej jakościowej różnicy pomiędzy narracją historyczną a fikcyjną, po nim zaś czynili to White, Franklin Ankersmit i inni, a w efekcie historia utraciła swoją uprzywilejowaną pozycję dostarczycielki weryfikowalnej prawdy na temat przeszłych wydarzeń.

By rozważyć kwestię związków oraz różnic pomiędzy stosowanymi przez historyków operacjami kontrfaktycznymi oraz literackimi historiami alternatywnymi, konieczne jest szkicowe nakreślenie historii tych obydwu form narracyjnych. Najpierw jednak trzeba zaznaczyć, że operacje kontrfaktyczne - czyli „hipotetyczna alteracja przeszłej sekwencji zdarzeń, która zmienia wydarzenia faktyczne, kreując ich alternatywny przebieg" [Danneberg 2008: 119] - nie ograniczają się li tylko do literatury, a już na pewno nie wyłącznie do historii alternatywnych [por. Danneberg 2008] ani do historii. Operacje kontrfaktyczne wykorzystuje się w socjologii, ekonomii, naukach politycznych, teologii, geografii, literaturoznawstwie [por. Black 2008: 2, 195]. Tak naprawdę kontrfaktualizm 
jest wysoce użytecznym narzędziem, które może zostać wykorzystane w niezliczonej ilości kontekstów, bo pozwala zmierzyć się z kwestią przyczynowości i sprawczości w życiu ludzkim, a także $\mathrm{z}$ jednym $\mathrm{z}$ najważniejszych trybów ludzkiego myślenia; jest też „manifestacją ludzkiej swobody narracyjnej” [zob. Rosenfeld 2005: 22-23; Danneberg 2008: 109; Kaye 2010: 41; por. Stemplewska-Żakowicz 2002: 99].

Korzenie kontrfaktualizmu tkwią głęboko w antyku. Już Herodot w swych Dziejach (księga VI i vII) posłużył się tym typem wnioskowania, opisując moment, kiedy to polimarch Kalimach, przekonany wcześniej przez Miltiadesa, podjął ostatecznie decyzję o przystąpieniu do bitwy z Persją pod Maratonem (49o r. p.n.e.). Wcześniej głosy dziesięciu strategów rozłożyły się po równo za przystąpieniem do bitwy i za oczekiwaniem na posiłki ze Sparty. Kalimach, podejmując ostateczną decyzję, wygłosił mowę, w której rozważył oba scenariusze (oczekiwania na pomoc i przystąpienie do bitwy). Tak naprawdę jednak to dopiero Tytus Liwiusz w Ab Urbe Condita (ks. 9 r. Xvi) stworzył historię alternatywną, opisując Aleksandra Wielkiego, który pokonuje plemiona zamieszkujące Półwysep Apeniński. Rzymski historyk był ciekaw tego, czy w tej sytuacji Aleksander Macedoński ruszyłby na Wschód, do Persji, czy zaspokoiłby swój głód władzy podbojami na Zachodzie. Liwiusz zastanawiał się również, czy dla republiki rzymskiej nie byłoby lepiej, gdyby Cezar nigdy się nie narodził (Seneka, Nat. Quaest. v, 18, 4 [cyt. za: Demandt 1999: 22]). Również w historiografii arabskiej dość wcześnie odnajdziemy przykłady operacji kontrfaktycznych. Historyk Ibn Kaldun (1332-1406), wbrew ścisłemu determinizmowi islamu, w swej Historii Arabów (Muqaddimah) rozważał scenariusz alternatywny, w którym za sprawą udanej sukcesji Alego, dominującym odłamem islamu staje się szyizm. Kontrfaktualizm był istotny również w historiografii Ottomańskiej Turcji [por. Black 2005: 37-38], zaś w historiografii indyjskiej i chińskiej był tak popularny, że odgrywał dominującą rolę w kształtowaniu się gatunków historycznych (tzw. lun), a w okresie panowania dynastii Tang (619-907 n.e.) był podstawą przeprowadzania egzaminów dla urzędników służby cywilnej [Black 2005: 38]. Otwarte pozostaje pytanie, czy Herodot i Liwiusz 
zdawali sobie sprawę z tego, że rozważając historyczne alternatywy, dokonują de facto rewolucji w historiografii, za której ojców obaj notabene (wraz z Tukidydesem) uchodzą? Pamiętajmy, że rozdział historii i literatury dokonal się dopiero w na przełomie wieków XVIII i XIX [Lemann 2012a]. Nic więc dziwnego, że pierwsze stricte literackie, powieściowe historie alternatywne ${ }^{5}$ powstały właśnie w tym czasie. Francuskie realizacje to Louisa Geoffroy-Château Histoire dla la monarchie universelle: Napoléon et lat conquete $d u$ monde (1812-1832) z roku 1836 i Charlesa Renouviera L'utopie dans l'histoire. Esquisse historique apocryphe du développement de la civilisation européenne tel qu'il n'a pas été, tel qu'il aurait pu être z $1867 \mathrm{r}$. Pierwsze historie alternatywne spisane w języku angielskim to nowela amerykańskiego pisarza Nathaniela Hawthorne'a, P's Correspondence z 1845 r., Alroy Benjamina Disrealego z 1833 r. czy też Marka Twaina Jankes na dworze króla Artura (1889) bądź Aristopia Castello Holforda z 1895 r. ${ }^{6}$.

Właśnie w XIX w. historie alternatywne zaczynają uchodzić za niezgodne z procedurami historii, podczas gdy jeszcze $w$ wieku XVIII historyk angielski Edward Gibbon rozważa losy Wielkiej Brytanii poddanej wplywowi islamu jako efekt przegranej przez Karola Młota bitwy pod Poiters w 733 r. Rozdzielenie operacji kontrfaktycznych i literackich historii alternatywnych dokonało się nieprzypadkowo w tym samym momencie, w którym powstała powieść historyczna. Od wieku XIX pojęcie literatury przestaje obejmować jak dotąd całość piśmiennictwa. Zaczyna się era pojmowania historii jako nauki, z której należy wyrugować wszelkie rezydua fikcji, a także te elementy, które mogą zachwiać wiarę w empiryczny i weryfikowalny charakter twierdzeń zawodowych historyków. Mówiąc metaforycznie, świeżo kreowany etos historyka wymagał ofiar. Jedną z nich było wyrugowanie z historii operacji kontrfaktycznych i przyznanie im miejsca w obrębie fikcji.

5 Dużo wcześniej epicką formę historii alternatywnej nadał Joanot Martorelli $\mathrm{w}$ roku 1490 romansowi epickiemu Tirant lo Blanc. Autor opisuje w nim rzeczywistość, w której dzięki waleczności tytułowego rycerza Porta Otomańska nie zdobyła Konstantynopola w roku 1453.

6 Osadnicy purytańscy w Virginii odkrywają złoto i dzięki temu budują utopijną kolonię. 
Simon Kaye [2010: 45] w swym tekście opublikowanym w prestiżowym periodyku „History and Theory”, dokonuje rozróżnienia na operacje kontrfaktyczne (historia) oraz historie alternatywne, „które mogą być uznane za rodzaj science-fiction”, trafnie zauważa, że „pierwsze historie alternatywne poprzedzają o wieki takie rozróżnienia gatunkowe”.

Operacje kontrfaktyczne były przedmiotem nauczania w szkołach wojskowych. Zwolennikiem tego typu dowodzenia był chociażby pruski generał i teoretyk wojny Klaus von Clausewitz (1780-1831), autor słynnego traktatu O wojnie. Dowodził w nim, że historyk wojskowości i przyszły dowódca winien uczyć się na błędach popełnionych przez innych. Co ciekawe, również w historiografii polskiej podejmowano w owym czasie kwestię rozważania historycznych alternatyw. Michał Bobrzyński (1849-1935) doradzał w roku 1879 daleko idącą ostrożność, choć uznawał, że „gdybanie” historyczne jest możliwe, ale jedynie pod pewnymi warunkami, które przytoczę poniżej [Bobrzyński 1974].

Powrót operacji kontrfaktycznych do historii dokonał się dopiero w początkach Xx w. W roku 1907 ukazała się książka Josepha Edgara Chamberlaina, polityka, skrajnego nacjonalisty i rasisty, The Ifs of History. W rozdziale If Columbus Had Kept His Straight Course Westward autor zastanawia się, jak wyglądałaby historia USA, gdyby konkwistadorzy wylądowali u zachodnich wybrzeży Ameryki Północnej. W roku 1931 wydano zbiór esejów kontrfaktycznych If it Had Happened Otwerwise pod redakcją J.C. Squire'a (sir John Collings Squire). Ów tom zdaniem Nialla Fergussona ośmieszył kontrfaktualizm historyczny na lata [Fergusson, ed. 1997: 9-14], albowiem napisała go „pstrokata banda historyków” [Fergusson, ed. 1997: 9], posługująca się myśleniem życzeniowym zamiast kontrfaktycznym. Tom esejów Squire'a doskonale ilustruje niebezpieczną tendencję historii alternatywnych podstawiania w miejsce pytania: „co by było, gdyby” kwestii: „gdyby tylko” [por. Black 2005: 5]. Squire [1907: VII; cyt. za: Kaye 2010: 49] we wstępie do tego tomu pisał: „[... nie ma akcji ani wydarzenia, wielkiego lub małego $[. .$.$] , które$ nie mogłoby się wydarzyć inaczej, prawdopodobnie modyfikując historię naszego świata”. To właśnie „dzięki” temu tomowi Edward 
Carr [1961: 90], znany i wplywowy historyk, nazwał historie alternatywne i kontrfaktualizm „salonową igraszką [parlour game N. L.] niemającą niczego wspólnego z historią". Carr na kilka dekad narzucił historykom negatywny stosunek do kontrfaktualizmu, tak iż dopiero Alexander Demandt [1999] swą Historią niebyłą zaczął z trudem wprowadzać go ponownie do historii. Na szczególną uwagę zasługuje esej Winstona Churchilla If Lee Had Not Won the Battle od Gettysburg, uznawany czasem za najsłynniejszy esej z zakresu historii alternatywnej, niewątpliwie po części za sprawą osoby autora. Churchill zastosował chwyt „alternatywnej historii alternatywnej", polegający na tym, że narrator diegetyczny - niejaki Winston M. Churchill, zapewne alternatywne alter ego, czy mówiąc zgodnie z językiem logiki formalnej: transświatowy odpowiednik przyszłego premiera Wielkiej Brytanii ${ }^{7}$ - opisuje świat alternatywny dla niego - świat naszej historii aktualnej. W tym eseju generał Lee wygrywa zarówno bitwę pod Gettysburgiem, jak i rychło po tym całą wojnę secesyjną, zatem świat, w którym Lee tę potyczkę przegrał jest według narratora diegetycznego absurdalny. Jak widać, już u początków zarania eseistyki kontrfaktualnej zdarzały się próby bardziej literackiego przedstawienia materii. Chwyt zastosowany przez Churchilla - esej ten był swoistą genologiczną hybrydą, na poły pracą historyka, a na poły opowiadaniem [por. Danneberg 2008: 202] - mimo iż nie mógł spotkać się z aprobatą ze strony Carra i innych zawodowych historyków, dowodzi, że rozważając scenariusze alternatywne historycznie, należy zdawać sobie sprawę $\mathrm{z}$ własnego usytuowania interpretacyjnego oraz pragnień kierowanych pod adresem nieziszczonej przeszłości. Zastosowana przez Churchilla perspektywa, zmierzająca do przyjęcia radykalnie odmiennego punktu oglądu, spowodowała, iż przyszły premier Wielkiej Brytanii nie przyjąl wykpionego przez Carra stanowiska życzeniowego wobec historii, a wręcz z punktu widzenia naszej historii aktualnej naszkicował czarny scenariusz. Rosenfeld

7 Termin „transświatowa identyfikacja” jest autorstwa Lubomira Doležela, zaś teoria odpowiedników (counterpart theory) - Davida Lewisa. Oba zjawiska wchodzą w skład tzw. teorii światów możliwych. Obaj badacze rozważają kwestię istnienia w światach alternatywnych odpowiedników osób ze świata aktualnego oraz stopnia ich podobieństwa wobec ich siebie. 
zauważa zaś, że czarne scenariusze, czyli opisanie alternatywnej przeszłości jako gorszej od aktualnej, są efektem koncyliacyjnego uznania, iż istniejący stan rzeczy, zgodnie z twierdzeniem Leibniza, jest najlepszym z możliwych. Churchill, pisząc swój esej, przyjął więc punkt widzenia Leibnizowskiej Teodyceii, która uznawana jest za tekst założycielski zarówno dla teorii wieloświata, jak i kontrfaktualizmu [por. Kaye 2010: 42; Gallagher 2012: 140].

Do nowatorskiej poetyki Churchilla nawiązał w pewien sposób Robert Sobel [1973], autor naukowej, historycznej monografii z 1973 r. For Want of a Nail: If Burgoyne Had Won at Saratoga. Sobel stworzył alternatywną historię świata, w którym generał Burgoyne zwyciężył w bitwie pod Saratogą w 1777 r., zduszając w zarodku amerykańską rewolucję. Historyk swej pracy z zakresu historii alternatywnej nadał kształt kroniki historycznej, zawierającej dzieje świata w ciągu następnych 200 lat. Owa kronika jest przeplatana fikcyjnymi przypisami i sfingowanymi źródłami historycznymi. Sobel celowo więc zaciera granice pomiędzy operacjami kontrfaktycznymi a literackimi historiami alternatywnymi, antydatując konstatacje współczesnych historyków, iż pomiędzy tymi dwoma formami wnioskowania, czy może raczej nadania owym wnioskom ostatecznego narracyjnego kształtu, nie ma radykalnej różnicy. Simon T. Kaye [2010: 45] mówi wprost: „[...] to ważne, by nie dokonywać zbyt ostro rozróżnienia na narracje świadomie «historyczne» i te, które są jawnie «fikcyjnie»”. Tim de Mey oraz Erik Weber [2003: 28] piszą: „Biorąc pod uwagę fakt, że ostatnimi czasy historycy są zainteresowani spekulacjami kontrfaktycznymi, oraz z uwagi na popularność gatunku science-fiction znanego jako historie alternatywne, przyznajmy, że granica pomiędzy dyskursem historycznym a fikcją jest płynna”. Ci ostatni badacze są jednak zdania, podobnie jak większość historyków, że nawet mimo tych zbieżności istnieje jakaś niezbywalna różnica pomiędzy literackimi historiami alternatywnymi a operacjami kontrfaktycznymi, podejmowanymi przez zawodowych historyków. Ostatnią kwestią, którą zamierzam w tym artykule rozważyć, jest właśnie pytanie, czy faktycznie istnieje taka różnica, czy też jej postulowanie jest jedynie pobożnym życzeniem historyków, tracących grunt pod nogami, a chcących wciąż wierzyć w to, że tertium non datur est. 
Aleksander Demandt [1999: 27], do niedawna główny promotor kontrfaktualizmu, postuluje między innymi, by wykazywać fałszywość powszechnych sądów o przyczynach „poprzez odrzucanie implikowanych przez nie kontrfaktycznych hipotez”. Ostrzega również przed osunięciem się w życzeniowość i wybieraniem jedynie pomyślnych hipotez, a więc takich, które zmieniłyby historię na lepsze, zgodnie z największymi pragnieniami historyka. Zwraca też uwagę na fakt, że momenty początkowe i przejściowe pewnych procesów dziejowych dają szczególną możliwość konstruowania wiarygodnych alternatyw [Demandt 1999: 37]. Co ciekawe, Demandt jest tutaj zgodny z fizykami mówiącymi o procesie „bifurkacji”, czyli nagłej i nieprzewidywalnej destabilizacji struktury poddanej intensywnemu naporowi (autorem terminu „bifurkacja” jest Ilja Prigożyn [por. Łotman 1997: 34]). Współcześnie historycy zajmujący się kontrfaktualizmem dużą wagę przywiązują do teorii fraktali, zbiorów Mandelbrota [Goddis 2002: 81-90] czy modelowania komputerowego zmian dla zwiększenia prawdopodobieństwa alternatywnych scenariuszy [Fergusson 2006]. Przypomnę, że pierwszą szkołą historyczną, która posługiwała się tym rodzajem myślenia, była tzw. Kliometria (New Economic History), która w badaniach nad historią gospodarczą posługiwała się ekonometrią. Najważniejszym przedstawicielem tej szkoły jest Robert Fogel [1964], laureat Nagrody Nobla w dziedzinie ekonomii (1993 r.), który zajmował się kwestią roli kolei w rozwoju usA (udowodnił, że kolej nie była do rozwoju niezbędna, gdyż tę samą rolę mógł odegrać transport rzeczny) oraz niewolnictwem (postulował, że zniesienie niewolnictwa było jedynie koniecznością polityczną, nie zaś ekonomiczną [Engerman, Fogel 1974]). Polski historyk Jerzy Topolski [1984] już w swych pracach z lat 70. i 8o. twierdził, że obecność wnioskowania kontrfaktycznego jest powszechna zarówno we wnioskowaniu, jak i w narracji historycznej, tak w rozważaniu przyczyn, jak też następstw zdarzeń w narracji historycznej oraz jako element myślenia poprzedzający spisanie narracji historycznej. Niestety, prace profesora Topolskiego nie były powszechnie dostępne w krajach anglojęzycznych, dlatego też Tim de May i Erik Weber [2003: 29] uznali, że to Johannes Bulhof [1999] zauważył, iż kontrfaktualizm jest obecny niemal w każdym tekście historiograficznym. 
Demandt zwraca też uwagę na niebezpieczeństwa płynące ze zbyt łatwego opierania alternatyw na tzw. teorii wielkiego człowieka w historii (hołdował jej Thomas Carlyle żyjący w latach 1795-1881), czyli wydłużenia lub skrócenia życia przywódców, monarchów, rewolucjonistów bądź przywódców religijnych. Demandt stawia tezę, że historyk alternatywista musi posługiwać się równie żelazną logiką co jego kolega zajmujący się historią klasyczną. Daleko wcześniej, bo w xıx stuleciu, Michał Bobrzyński [1974: 426] uznał, że operacje kontrfaktyczne powinny spełniać następujące warunki:

[...] możliwe i pożyteczne, jeżeli 1) przypuszczenie faktyczne, na którym się opiera, jest prawdziwe lub w danej chwili możliwe; 2) jeżeli wniosek z przypuszczenia wyprowadzony, uzasadniony jest w umiejętności; 3) jeżeli postawienie przypuszczenie i wyprowadzenie wniosku objaśnia istotnie różne kierunki i drogi, których w danej chwili naród lub osobistość historyczna mogły były się chwycić.

Ani Bobrzyński, ani Demandt nie podali jednak satysfakcjonującej odpowiedzi na pytanie o to, jak odróżnić wiarygodny scenariusz alternatywny od tego niewiarygodnego.

Topolski [1999], w artykule poświęconym historii alternatywnej, twierdzi, że tzw. narracje nieprawomocne, kontrfaktyczne, polegające na negowaniu znanego $\mathrm{z}$ historii ciągu zdarzeń, mogą jednak mieć pewne znaczenie dla pracy historyka. Takie narracje nieprawomocne przeciwstawia narracjom fantazjującym, „science fiction skierowanym w przeszłość” [Topolski 1999: 3], a jako przykład takich narracji podaje między innymi pisarstwo Teodora Parnickiego. Topolski [1999: 6] uznaje, że na historię składają się nie tylko te wydarzenia, które faktycznie miały miejsce w rzeczywistości, ale również ich alternatywy. Wymieniając typy historii alternatywnych, zauważa jednak, że owe narracje fantazjujące, „będące narracją nieprawomocną, choć w pewnych przypadkach, gdy siłę danego czynnika, którego działanie kontrfaktycznie się zawiesza, można w jakimś stopniu zmierzyć, taka narracja historyczna może stać się prawomocną, tzn. być uznaną za taką" [Topolski 1999: 4; 
wyróż. - N.L.]. Widać więc wyraźnie, że dystynkcja pomiędzy narracją nieprawomocną (kontrfaktualizm, historia alternatywna historyczna) a fantazjującą (czysta fikcja, science fiction, literacka historia alternatywna) jest jedynie uznaniowa. Topolski [1999: 8] nie podaje też wyraźnych kryteriów, według których miałoby się dokonać takie rozróżnienie, proponuje jedynie formulę „minimalnej charakterystyki rzeczywistości", która polega na obiektywnym spojrzeniu na proces dziejowy, zakładającym, że ludzie w historii działają w obrębie pewnych konkretnych możliwości i warunków. Ta koncepcja jest zbieżna z tzw. formułą minimalnego przepisania historii (minimal-rewrite-of-history), zgodnie z którą formulując alternatywę, należy zmienić jak najmniej [Hawthorne 1991; Belkin, Tetlock, eds. 1996; de Mey, Weber 2003: 28].

Pojawia się więc pytanie: jak zmierzyć owo „jak najmniej”? Zwłaszcza, że cytowany uprzednio Topolski [1999: 6] posługuje się sformułowaniem: „zbyt swobodne operowanie założeniami alternatywnymi”. Krzysztof Brzechczyn [2005: 87] proponuje podział na płytką i głęboką analizę historii alternatywnej, w którym płytka analiza wskazuje jedynie na te momenty dziejowe, kiedy mogły się owe alternatywy pojawić, zaś głęboka analiza wskazuje na ich dalsze następstwa. Eksplanacyjna historia alternatywna polega natomiast zdaniem badacza na tym, że historyk „spośród puli alternatyw wyróżnia $[\ldots]$ i rozpatruje te alternatywne ciągi wydarzeń, które wświetle wiedzy historyka (jej elementem jest również rekonstrukcja wiedzy działających w przeszłości aktorów) były najbardziej prawdopodobne" [Brzechczyn 2005: 88]. Znów uderza nieostre sformułowanie: „najbardziej prawdopodobne”. Historia eksplanacyjna jest jednak wyraźnie przeciwstawiona jako lepsza gorszej historii aksjologicznej, zwanej inaczej historią życzeniową, której „punktem wyjścia jest stan rzeczy najwyżej ceniony w systemie wartości historyka" [Brzechczyn 2005: 87]. Badacz dokonuje dalszych rozważań, które tutaj pominę; skupię się jednakże na jego ocenie niektórych prac zawodowych historyków. Brzechczyn zauważa, że pionierem kontrfaktualizmu w historiografii polskiej był Jerzy Łojek, autor między innymi Szans powstania listopadowego (1966) książki, w której uznał, że powstanie listopadowe miało szanse, by zakończyć się sukcesem. Jerzy Łojek [1991: 8] uznał za oczywiste, 
że wszystkie bez wyjątku procesy historyczne od największych przemian społeczno-ekonomicznych po wypadki polityczne kształtujące oblicze poszczególnych państw czy części świata na okres życia jednej lub kilku najwyżej generacji, miały w momencie swego zarania i w czasie rozwoju wyraźne alternatywy. Początek każdego procesu, najwyraźniej jest to zresztą zauważalne w historii wielkich politycznych i militarnych konfliktów ludzkości, podobny jest do wejścia na rozstaje dróg w pierwszej fazie od siebie nieodległych, lecz dalej rozgałęzionych coraz większą przestrzenią. Chwila wejścia na ten rozstaj dróg dziejowych była czasami jedynie przelotnym momentem historii, nie zawsze zresztą przez historiografię zauważonym. Niekiedy tylko zbieg okoliczności, częściej świadoma swych celów, lecz nieświadoma konsekwencji działania, decyzja ludzka przesądzała o skierowaniu biegu historii w jednym lub drugim kierunku... A czasami możliwości tych było więcej. Upieranie się przy badaniu tylko tej linii rozwoju, która rzeczywiście się zrealizowała, zuboża niesłychanie wiedzę ludzką.

Aplikując rozróżnienia własne oraz Topolskiego, Brzechczyn [2005: 90] uznaje, że przyjęcie wariantu zwycięskiego powstania z 1830 r. według kryteriów Topolskiego byłoby nierealną alternatywą historyczną, podczas gdy dla Łojka była to realistyczna, choć niezrealizowana alternatywa historyczna. Jak widać, ostateczna decyzja wciąż ma charakter uznaniowy, a ponieważ zarówno Topolski, jak i Brzechczyn stwierdzili, że główną rolę odgrywają tu zarówno wiedza, jak i pragnienia historyka wobec przeszłości, kwestie dobrego lub złego kontrfaktualizmu wydają się być prawdziwym węzłem gordyjskim, który spleciono z kwestii wiarygodności oraz obiektywizmu versus niezbywalnej narracyjności i subiektywizmu narracji historyka. Nade wszystko jednak Szanse powstania listopadowego zostały uznane za przykład alternatywnej historii aksjologicznej, ponieważ dla Łojka najważniejszą kwestią była polska autonomia polityczna. Jest to zarzut dość poważny, aczkolwiek wydaje się, że można go zastosować do większości historii alternatywnych, zwłaszcza tych spisanych przez historyków. Paweł Wieczorkiewicz uważał, że Polska powinna była w przededniu 
II wojny światowej wybrać sojusz z Hitlerem; uznał też, że historia potoczyłaby się inaczej, gdyby marszałek Piłsudski mógł dłużej żyć. Tą samą drogą poszedł w swych powieściach Marcin Wolski (Alterland, Wallenrod, Mocarstwo) oraz Piotr Zychowicz w rozbudowanym eseju, zawierającym literackie elementy mimetyzmu formalnego (sfingowane listy, fragmenty alternatywnych powieści, reportaży itp.) Pakt Ribbentrop-Beck, czyli jak Polacy mogli u boku III Rzeszy pokonać Zwiazek Sowiecki [por. Lemann 2014a]. Toynbee oraz Parnicki marzyli o tym, by dłużej mógł żyć Aleksander Macedoński. Przykładów jest wiele.

Co szczególnie istotne, okazuje się, że większą skłonność do snucia czarnych scenariuszy, opisu dystopijnego przebiegu dziejów, mają nie historycy, a pisarze. Lektura pracy Gavriela Rosenfelda [2005] o alternatywnych historiach III Rzeszy dowodzi, że tego typu powieści stanowią zdecydowaną większość. Zwycięstwo Hitlera nie jest jedynym czarnym scenariuszem chętnie rozważanym przez pisarzy. Inne to na przykład brak reformacji w Wielkiej Brytanii (Alteracja Kingsleya Amisa, Pavane Keitha Robertsa), brak wolnej Polski w xx w. (Lód Jacka Dukaja, Polska nie istnieje Wojciecha Orlińskiego). Literatura może również sięgać po nieobecne w operacjach kontrfaktycznych POD (point of divergence), chociażby rozważając alternatywę w skali mikrohistorii - taką, która nie wpłynie znacząco na losy świata (Connie Willis, Księga Sądu Ostatecznego); pokazać, że zmiana historii może dokonać się przy pomocy pomijanych w rozważaniach historyków danych fizycznych i klimatycznych: „[...] żadne środowisko przyrodnicze nie oddziałuje na ludzi, tak jak na przykład ciepło czy zimno oddziałuje na termometr" [Topolski 1999: 8; por. Black 2008: 1]. Wymienić tutaj można powieści Dukaja: Lód (upadek meteorytu tunguskiego zamraża historię) i Inne pieśni (świat oparty na fizyce Empedoklesa z Akragas i hylemorfizmu Arystotelesa) czy Burzę Macieja Parowskiego (we wrześniu 1939 r. Polskę uratowały ulewne deszcze, niepozwalające wtargnąć oddziałom niemieckim w głąb kraju).

Może zatem - paradoksalnie - literackie historie alternatywne nie tylko nie są gorszą, bo mniej wiarygodną, siostrą kontrfaktualizmu, ale wręcz mają do zaoferowania coś więcej niż naukowe rozważania nad możliwymi dziejowymi alternatywami? 


\section{Bibliografia}

Arystoteles (1983), Poetyka, przel. i oprac. Henryk Podbielski,

Ossolineum, Wrocław.

Balcerzan Edward (1999), W stronę genologii multimedialnej, „Teksty

Drugie", z. 2, s. 7-24

Barthes Roland (1984), Dyskurs historii, przeł. Adam Rysiewicz

i Zbigniew Kloch, „Pamiętnik Literacki”, z. 3, s. 237-256.

Belkin Aaron, Tetlock Philip E., eds. (1996), Counterfactual Thought

Experiments in World Politics: Logical, Methodological, and Psychological

Perspectives, Princeton University Press, Princeton-New York.

Hawthorne Geoffrey (1991), Plausible Worlds: Possibility and

Understanding in History and the Social Sciences, Cambridge

University Press, Cambridge.

Black Jeremy (2005), Using of History, Hodder Arnold, London.

Black Jeremy (2008), What If? Counterfactualism and the problem of history, The Social Affairs Unit, London.

Brooke-Rose Christine (1996), Historia palimpsestowa, w: Umberto

Eco, Richard Rorty i in., Interpretacja i nadinterpretacje, red. Stefan

Collini, przeł. Tomasz Bieroń, Znak, Kraków, s. 123-134.

Brzechczyn Krzysztof (2005), O odmianach historii alternatywnej,

w: Gra i konieczność. Zbiór rozpraw z filozofii historii i historii

historiografii, red. Grzegorz A. Dominiak, Janusz Ostój-Zagórski,

Wojciech Wrzosek, Epigram, Bydgoszcz, s. 87-93.

Bulhof Johannes (1999), What If? Modality and History, „History and

Theory", vol. 38, s. 145-168.

Carr David (1961), What is History?, Cambridge University Press,

Cambridge.

Certeau de Michel (2001), Pismo historii, przeł. Krzysztof Jarosz, „Er(r)go”, nr 3, s. 109-137.

Danneberg Hilary P. (2008), Coincidence and Counterfactuality Plotting

Time and Space in Narrative fiction, University of Nebraska Press,

Nebraska.

Demandt Alexander (1999), Historia niebyła. Co by byto, gdyby...?, PIw, [oryg. wyd. 1984], Warszawa.

Domańska Ewa (2011), Antropologia literatury - projekt interdyscyplinarny czy transdyscyplinarny?, „Przegląd Kulturoznawczy”, nr 1, s. 55-64.

Elias Amy (2001), Sublime Desire. History and Past-196o Fiction, The John Hopkins University Press, Baltimore.

Engerman Stanley L, Fogel Robert (1974), Time on the Cross:

The Economic if American Negro Slavery, vol. 2., W.W. Norton and Company, New York. 
Fergusson Nial, ed. (1997), Virtual History: Alternatives and

Counterfactauls, Basic Books, New York.

Fergusson Niall (2006), How to Win the War, „New York Times

Magazine", October 16th, [dostęp: 10 grudnia 2015], http://nymag. com/news/features/22787.

Fogel Robert (1964), Railroads and American Economic Growth: Essays in Econometric History, John Hopkins Press, Baltimore.

Gallagher Catherine (2012), Dlaczego opowiadamy, jak nie byto, przeł.

T. Bilczewski, A. Kowalcze-Pawlik, „Teksty Drugie” nr 1-2, s. 138-152.

Geertz Clifford (1996), O gatunkach zmąconych (Nowe konfiguracje myśli społecznej), przeł. Zdzisław Łapiński, w: Postmodernizm. Antologia przekładów, red. Ryszard Nycz, Wydawnictwo Baran i Suszyński, Kraków, s. 214-235.

Goddis John Lewis (2002), The Landscape of History, Oxford University Press, Oxford. Bobrzyński Michał (1974), Wimię prawdy dziejowej, w: tegoż, Dzieje Polski w zarysie, oprac. Michał Serejski, Andrzej Feliks Grabski, PIw, Warszawa.

Hellekson Karen (2001), The Alternate History. Refiguring Historical Time, The Kent State University Press, Kent, Ohio-London.

Hutcheon Linda (1997), Historiograficzna metapowieść: parodia i intertekstualność historii, przeł. Janusz Margański, w: Postmodernizm. Antologia przekładów, red. Ryszard Nycz, Kraków, s. 378-398.

Janion Maria (2001), Zto i fantazmaty. Prace wybrane, t. 3, Universitas, Kraków.

Jenkins Henry (2007), Kultura konwergencji. Zderzenie starych i nowych mediów, przeł. Małgorzata Bernatowicz, Mirosław Filiciak, Wydawnictwa Akademickie i Profesjonalne, Warszawa.

Kaye Simon T. (2010), Challenging Certainty: The Utility and History of Counterfactualism, „History and Theory”, nr 49, s. 38-57.

Kula Marcin (2011), Reportaż historyczny jako rodzaj wspótczesnej historiografii, w: Historia w kulturze wspótczesnej. Niekonwencjonalne podejścia do przeszłości, red. Piotr Witek, Mariusz Mazur, Ewa Solska, Wydawnictwo UmCs, Lublin, s. 297-311.

Lemann Natalia (2007), Pomiędzy literatura a historia - epicka historiografia, „Zagadnienia Rodzajów Literackich”, z. 1-2 (99-100), s. 153-177.

Lemann Natalia (2008), Epicka historiografia we wspótczesnej prozie polskiej, Wydawnictwo Uniwersytetu Łódzkiego, Łódź.

Lemann Natalia (2011), Czy można uchronić się od przeszłości? Historie alternatywne i uchronie jako literackie aporie polityki i wiedzy 
historycznej, „Zagadnienia Rodzajów Literackich, t. 54, z. 2 (108), s. 339-356.

Lemann Natalia (2012a), Literatura, historia, kultura popularnaprzestrzenie konwergencji. Wprowadzenie, „Zagadnienia Rodzajów Literackich", z. 2 (110), s. 123-148.

Lemann Natalia (2012b), Stownik rodzajów i gatunków literackich, red. Grzegorz Gazda, Słowinia Tynecka-Makowska, PwN, Warszawa, s. 38o-388.

Lemann Natalia (2013), Czy historia może być skandalem? Rzecz o historiach alternatywnych $i$ ich sporach $z$ przeszłościa/teraźniejszościa, w: Skandal w kulturze europejskiej i amerykańskiej, red. Bożena Płonka-Syroka i in., DIG, Warszawa, s. 123-138.

Lemann Natalia (2014a), Alternatywna miara wielkości? Postkolonialne uwarunkowania wizji hegemonicznej przeszłości Polski w wybranych historiach alternatywnych, „Porównania. Czasopismo Poświęcone Zagadnieniom Komparatystyki Literackiej oraz Studiom Interdyscyplinarnym”, nr 14, s. 19-41.

Lemann Natalia (2014b), Steampunk, „Zagadnienia Rodzajów Literackich", t. 57, z. 1 (113), s. 344-349.

Lubelski Tadeusz (2012), Historia niebyta kina PRL, Znak, Kraków.

Łojek Jerzy (1991), Wokót sporów i polemik, Wydawnictwo Lubelskie, Lublin. Łotman Jurij (1997), Wola boska czy gra hazardowa (prawidtowość i przypadek w procesie historycznym), przeł. Bogusław Żyłko, „Konteksty. Polska Sztuka Ludowa”, nr 1-2, s. 32-35.

Maternicki Jerzy (1984), O nowy ksztatt edukacji historycznej, wsiP, Warszawa.

Maternicki Jerzy (1990), Historia i wychowanie, wsip, Warszawa.

Maternicki Jerzy (1998), Edukacja historyczna młodzieży - problemy $i$ kontrowersje u progu XXI wieku, TNOiK „Dom Organizatora”, Toruń.

Mey de Tim, Weber Erik (2003), Explanation and Thought Experiments in History, „History and Theory”, vol. 42, nr 1, s. 28-38.

Nycz Ryszard (1984), Sylwiczność literatury. Problem konstrukcji tekstu, Ossolineum, Wrocław.

Nycz Ryszard (2006), Kulturowa natura, staby profesjonalizm. Kilka uwag o przedmiocie poznania literackiego i statusie dyskursu literaturoznawczego, w: Kulturowa teoria literatury. Główne pojęcia i problemy, red. Michał Paweł Markowski, Ryszard Nycz, Universitas, Kraków, s. 5-38.

Phillips Mark (2011), Mikroskopowe i literackie historie. Problemy gatunkowości i dystansu, przeł. M. Wróblewski, J. Płuciennik, „Teksty Drugie”, nr 4, s. 127-145. 
Pomian Krzysztof (2006), Historia. Nauka wobec pamięci, Wydawnictwo UMCs, Lublin.

Radomski Andrzej (2012), Internet - Nauka - Historia, Wiedza i Edukacja, Lublin.

Rosenfeld Gavriel (2002), Why do we ask „what if?”. Reflections on the function of alternate history, „History and Theory”, vol. 41, s. 90-103.

Rosenfeld Gavriel (2005), The World Hitler Never Made. Alternate History and The Memory of Nazism, Cambridge University Press, Cambridge.

Roth Philip (2007), Spisek przeciwko Ameryce, przeł. Jolanta Kozak, Czytelnik, Warszawa.

Sawicki Stefan (1976), Gatunek literacki: pojęcie klasyfikacyjne, typologiczne, politypiczne, w: Problemy metodologiczne wspótczesnego literaturoznawstwa, red. Henryk Markiewicz i Janusz Sławiński, Wydawnictwo Literackie, Kraków.

Skwarczyńska Stefania (1970), Niedostrzeżony problem podstawowy genologii, w: Wokól teatru i literatury, PAx, Warszawa.

Sobel Robert (1973), For Want of a Nail: If Burgoyne Had Won at Saratoga, Greenhill Books, London.

Stemplewska-Żakowicz Katarzyna (2002), Koncepcje narracyjnej tożsamości, w: Narracja jako sposób rozumienia świata, red. Jerzy Trzebiński, Gdańskie Wydawnictwo Psychologiczne, Gdańsk, s. 81-114.

Topolski Jerzy (1984), Metodologia historii, wyd. 3, PWN, Warszawa.

Topolski Jerzy (1999), Refleksje na temat historii alternatywnej, „Przegląd Humanistyczny", nr 2/3 (353/354), s. 1-11.

White Hayden (2009), Proza historyczna, red. Ewa Domańska, przeł. Rafał Borysławski i in., Universitas, Kraków.

White Hayden (2014), Przeszłość praktyczna, red. Ewa Domańska, przeł. Jan Burzyński i in., Universitas, Kraków.

Zeidler-Janiszewska Anna (2006), „Visual Culture Studies” czy antropologicznie zorientowana "Bildwissenschaft?" O kierunkach zwrotu ikonicznego w naukach o kulturze, „Teksty Drugie”, nr 4, s. 9-30

\section{Natalia Leman}

\section{Alternative history - between historical writing and fantastic} literature or sometimes tertium est datur

The aim of this article is to define alternative history genre (branch of fantastic literature) as a participating in the historical writing formula (H. White). The author juxtaposes literary studies, literature and history 
as neighboring branches of humanistic knowledge. Alternate history genre could be displaced as displaced by both, the history and literary studies. This genre, as a type of fantastic literature, is understood as dangerous phantasm, because of fictional abilities. In this article historiography and literary studies are diagnosed as forming a sisterhood relationship. When the opportunity arises, it is shown that the idea of postmodern history is no novelty, since until the decline of the 18 th century history did not stand in oppossition to literature. Actually, the way of thinking about history as an (literary) art has a splendid tradition rooted in antiquity. It is shown that, in fact, there is no essential difference between alternate history (as a branch of fantastic literature) and counterfactualism as a methodology of history. It drives the author to a conclusion - by comparison of the methodologies of history and literary studies in the field of narrativity, and, according to Hayden White, comprehends history as a type of fiction, historio-graphia, literary artifact, or historical writing - that the alternative history novel could be understood as a third path to reconcile literary studies and historical studies.

The participation of popular culture, where the alternate history genre and fantastic literature traditionally belongs, makes the history and literary studies more transgressive, widely open for the contemporary forms of communication and more hearable.

Keywords: fantastic literature; alternative history; historiography; epistemology of history; historical writing; genology; transdisciplinarity; cultural studies.

Natalia Lemann - adiunkt w Katedrze Teorii Literatury (Instytut Kultury Współczesnej) Uniwersytetu Łódzkiego. Ma podwójne magisterium: $\mathrm{z}$ historii i z filologii polskiej. Zainteresowania naukowe badaczki koncentrują się głównie wokół związków literatury z naukami historycznymi (epistemologią i metodologią), dotyczą antropologii literatury, komparatystyki literackiej i literatury fantastycznej. Opublikowała miedzy innymi monografię Epicka historiografia we wspótczesnej prozie polskiej (2008) oraz sześćdziesiąt artykułów naukowych zamieszczonych w periodykach akademickich, monografiach i tomach zbiorowych. Obecnie pracuje nad monografią dotyczącą gatunku historii alternatywnych. Temu tematowi poświęciła już kilkanaście artykułów zamieszczonych w głównych periodykach naukowych, tj. „Zagadnieniach Rodzajów Literackich”, „Postscriptum Polonistycznym” oraz „Porównaniach. Czasopiśmie Poświęconym Zagadnieniom Komparatystyki Literackiej oraz Studiom Interdyscyplinarnym”. 